\title{
The Readability of Elementary School Level Textbooks with Raygor Graphics in the Context of Indonesian Language Education
}

\author{
B Sumadyo, S Setiawati, Sumarti, H Hilaliyah, Y Agustin, I Nafilah \\ Department Indonesian Language Education, Faculty of Language and Art, \\ Universitas Indraprasta PGRI, Jakarta, Indonesia \\ sulisjbsi@gmail.com
}

\begin{abstract}
Textbooks are books that are used as standard references on certain subjects as supporting learning goals. One of the requirements of a good textbook is that the readability level is in accordance with the level of the target student class. This study aims to determine the level of readability of Indonesian textbooks Curriculum 2013 level of elementary school. The method used is descriptive analysis using Raygor graphics. The sample in this study were twelve texts from the Indonesian language book Curriculum 2013 class V. Each one theme was taken one text. The results showed that for grade $\mathrm{V}$ Indonesian textbooks, of the twelve texts analyzed, one text did not meet the criteria for analysis $(8,3 \%)$, nine texts did not match the readability level $(75 \%)$, and two texts were appropriate $(16,7 \%)$. Overall, it can be concluded that the readability of the Indonesian textbook Curriculum 2013 at the grade $\mathrm{V}$ level of elementary school is not in accordance with the target students if measured using Raygor graphics. However, another interesting finding in the textbook is that there is a small dictionary at the bottom of each text that contains an explanation of some vocabulary related to the text presented.
\end{abstract}

Keywords: Readability; Textbook; Raygor Graphics

\section{INTRODUCTION}

One of the government's efforts to improve the quality of formal education in Indonesia is to improve the curriculum. The curriculum is a set of plans and arrangements regarding the purpose, content, and material of learning and the methods used as guidelines for the implementation of learning activities to achieve certain educational goals [1]. In Indonesia, the Curriculum currently in effect is the Curriculum 2013. 
The curriculum 2013 was designed with the aim of preparing Indonesian people to have the ability to live as individuals and citizens who are faithful, productive, creative, innovative, and affective and contribute to the life of the world, nation, state, and world civilization [2]. In its application at the Primary School level, these objectives are concrete using a thematic approach.

The thematic approach integrates various competencies from various subjects in various themes. Shoemaker explained that an integrated curriculum (thematic) is education that is organized in such a way that it crosses subject lines [3]. In its presentation, these subjects are summarized in one textbook, namely thematic textbook. For Indonesian language subjects, some publishers publish these subject books in a separate textbook separate from thematic books. Separation is intended so that students get more in-depth knowledge in each subject.

Textbooks are mandatory reference books to be used in schools that contain learning materials in order to increase faith and devotion, character and personality, mastery of science and technology, sensitivity and aesthetic abilities, physical and health potential arranged according to standards national education [4]. These standards are set by the National Education Standards Agency or BNSP, one of which is to determine the standardization of the quality of textbooks.

Textbooks are divided into two types namely main textbooks and supplementary textbooks [5]. The main textbook contains the main material in learning while the supplementary textbook is a book that helps the main textbook. Textbooks can also be referred to as textbooks, namely those that are used as standard references on certain subjects with characteristics as a source of teaching material, become a standard reference for certain subjects, arranged systematically and simply, and accompanied by instructions for learning [6]. The characteristics of the textbook can be used as a guide by the teacher in choosing and or writing a textbook. However, in addition to paying attention to its characteristics, the teacher should also understand the criteria of a good textbook, which is accurate with scientific development, relevant to basic competencies, communicative, systematic, student-oriented, in accordance with the ideology of the nation and state, using language rules correctly, and the level of readability is in accordance with the target students [6]. Reading texts that have good reading must be in accordance with the level of the target audience and not complicate students [7].

Readability comes from the word readability, which comes from the readable word can be defined as readable or legible. Readability is a measure of the suitability of reading material with the reader seen from the level of difficulty and ease of the text of the discourse [8]. This level of legibility is expressed in the form of class rank. By measuring the readability of a discourse, it will be able to determine the suitability of the reading material with a certain class rating.

There are many measuring devices that can be used to identify the readability level of a textbook, and two of them are Fry Graphics and SMOG Formula. Those two measuring devices had been discussed in the research by Mostafa Zamanian and Pooneh Heydari [9]. Besides those two, there is another measuring device, that is, Raygor Graphics.

In this study, the measuring instrument used to measure the readability of Indonesian textbooks at Elementary School level was Raygor Graphics. Raygor charts measure readability based on sentence length and length of words. The longer a sentence is, the harder it is to read by certain reading abilities. Likewise with the length of the word. The longer a word is, the harder it will be to read. 


\section{METHOD}

The method used in the research is descriptive analysis with data collection techniques through documentation [10]. The sample in this study were twelve texts from the Indonesian Language Curriculum 2013 at the Grade V Elementary School level.

The data analysis phase carried out is (1) determining one text from each theme; (2) counting one hundred words from each text; rows of numbers not taken into account; (3) count the number of sentences; (4) counting the number of difficult words, namely words consisting of six letters or more. In this study, the name of a person, place, and number are not included in criteria; (5) the results of steps 3 and 4 are plotted into Raygor's graphics; (6) interpret the readability level. The results of analyzing the overall data can be accessed via https://osf.io/h8ea6/ open the Science Framework [11].

All information about the text as a sample in this study is managed responsibly. In addition, there are no benefits provided by Researchers and / or publishers related to textbooks analyzed in this study.

\section{RESULTS AND DISCUSSION}

\subsection{How to use Raygor graphics}

In Raygor's graphics, the class ranking dividing lines appeared to be radiating upward. The horizontal line at the bottom of the graph shows the number of difficult words. Difficult words referred to here are words consisting of six letters or more. Vertical lines on the right and left sides of the graph show the number of sample sentences in the nearest ten.

The first step in using Raygor's graphics is to choose a representative discourse and then decapitate the hundredth word. Representative means sample discourse that truly reflects the reading text, ie without images, graphics, tables, formulas, or page blanks. Second, calculate the average number of sentences from the one hundred words to the nearest ten. Third, calculate the average number of difficult words per hundred words, namely words formed by six letters or more. Fourth, look for the meeting point of the results of the second and third steps

The word difficult in this study is a word consisting of six letters or more. Words in the form of people's names and place are not considered difficult because the length of a name does not affect one's understanding.

The following is a Raygor Graphics:

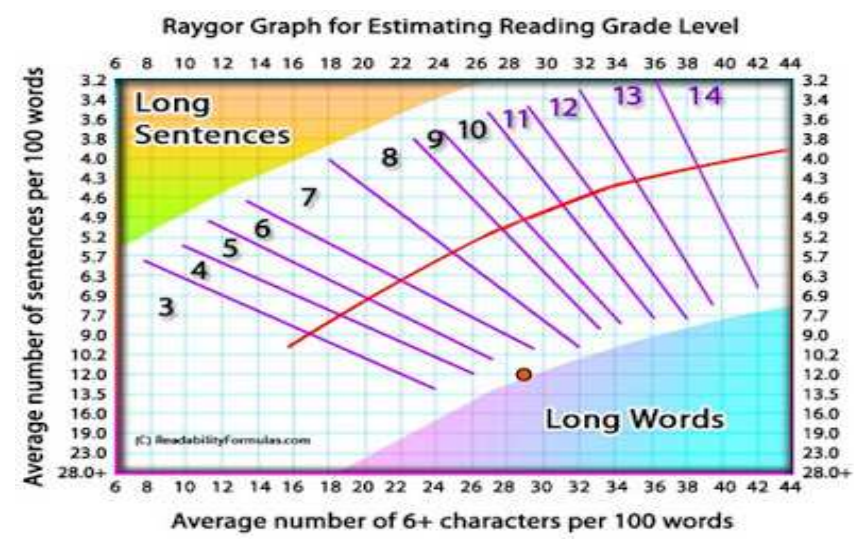




\subsection{Readability measurement results}

The readability level of a textbook can be identified after analyzing each text used as sample. Indonesian language textbooks The 2013 curriculum for Elementary School consists of 12 themes. In each theme there are several texts that are adapted to the content with the themes and competencies to be achieved. Next, the researcher selects one text for each theme presented.

The analyzed texts which represent each theme are "Laskar Pelangi" (song's lyric), "Hutan Kalimantan sebagai Paru-Paru Dunia", "Kenangan Manis Nesia bersama Nenek Kartika", "Bagaimana Proses Ektraksi Temulawak?", "Borobudur, Mahakarya Budaya Indonesia", "Berkenalan dengan Cakra si Pendaki Gunung", "Alat Musik Gendang", "Berkunjung ke Museum Bank Indonesia", "Kak Butet Manurung, Antropolog Peraih berbagai Penghargaan Internasional", "Garuda Sang Pelindung Nusantara", "Proses Tenun Ikat Sumba Timur", and "Petualangan Mona". Based on the results of the analysis, of the 12 texts analyzed there was one text that did not meet the criteria for analysis because the number of words did not reach one hundred words, nine texts are not suitable and only two texts are suitable for their readability.

The nine texts that their readability is not suited to Grade V of Elementary School are due to the number of sentences of per hundred words and words whose number is six or more in each text. The readability level of those texts can be downgraded by two ways. First, changing relatively long sentences (compound sentences) into simple sentences. Second, replacing long words with other shorter words but similar in meaning.

\section{Example 1:}

Borobudur dibangun di perbukitan, terbentang seluas $15.129 \mathrm{~m}^{2}$ dan tersusun atas lebih dari $50.000 \mathrm{~m}^{3}$ batu andesit. (The fifth text)

\section{Revision:}

Borobudur dibangun di perbukitan. Borobudur terbentang seluas $15.129 \mathrm{~m}^{2}$ dan tersusun atas lebih dari $50.000 \mathrm{~m}^{3}$ batu andesit.

Example 2:

Oh ya, perkenalkan, saya Cakra... (The sixth text)

Revision:

Oh ya, nama saya Cakra...

The results of overall text analysis, presented in the two following tables: 
Table 1 Number of Sentences and Difficult Words in each Text

\begin{tabular}{cccc}
\hline No. & Themes of the Text & $\begin{array}{c}\text { Number of Sentences } \\
\text { per One Hundred }\end{array}$ & $\begin{array}{c}\text { Words of Difficult } \\
\text { Words }\end{array}$ \\
\hline 1 & 1 & - & - \\
\hline 2 & 2 & 9 & 38 \\
\hline 3 & 3 & 9 & 27 \\
\hline 4 & 4 & 6 & 54 \\
\hline 5 & 5 & 10 & 49 \\
\hline 6 & 6 & 7 & 18 \\
\hline 7 & 7 & 11 & 42 \\
\hline 8 & 8 & 9 & 35 \\
\hline 9 & 9 & 8 & 40 \\
\hline 10 & 10 & 8 & 53 \\
\hline 11 & 11 & 8 & 29 \\
\hline 12 & 12 & 9 & 32 \\
\hline
\end{tabular}

Table 2 Recapitulation of Text Readability Levels with Raygor Graphics

\begin{tabular}{|c|c|c|c|}
\hline $\begin{array}{l}\text { No. } \\
\text { Text }\end{array}$ & Title Theme & $\begin{array}{c}\text { Level of } \\
\text { Readability }\end{array}$ & Description \\
\hline 1 & "Laskar Pelangi" (lirik lagu) & - & $\begin{array}{l}\text { The number of words in the } \\
\text { song lyrics is not up to one } \\
\text { hundred words so that it does } \\
\text { not meet the criteria for } \\
\text { analysis of readability. }\end{array}$ \\
\hline 2 & $\begin{array}{l}\text { Hutan Kalimantan sebagai Paru- } \\
\text { Paru Dunia }\end{array}$ & 11 & It is not in accordance with \\
\hline 3 & $\begin{array}{c}\text { Kenangan Manis Nesia bersama } \\
\text { Nenek Kartika }\end{array}$ & 5 & Corresponding \\
\hline 4 & $\begin{array}{c}\text { Bagaimana Proses Ekstraksi } \\
\text { Temulawak? }\end{array}$ & 14 & It is not in accordance with \\
\hline 5 & $\begin{array}{l}\text { Borobudur, Mahakarya Budaya } \\
\text { Indonesia }\end{array}$ & 14 & It is not in accordance with \\
\hline 6 & $\begin{array}{l}\text { Berkenalan dengan Cakra Si } \\
\text { Pendaki Gunung }\end{array}$ & 5 & Corresponding \\
\hline 7 & Alat Musik Gendang & 13 & It is not in accordance with \\
\hline 8 & $\begin{array}{l}\text { Berkunjung ke Museum Bank } \\
\text { Indonesia }\end{array}$ & 10 & It is not in accordance with \\
\hline 9 & $\begin{array}{l}\text { Kak Butet Manurung, } \\
\text { Antropolog Peraih berbagai } \\
\text { Penghargaan Internasional }\end{array}$ & 12 & It is not in accordance with \\
\hline 10 & $\begin{array}{c}\text { Garuda Sang Pelindung } \\
\text { Nusantara }\end{array}$ & 14 & It is not in accordance with \\
\hline 11 & $\begin{array}{c}\text { Proses Membuat Tenun Ikat } \\
\text { Sumba Timur }\end{array}$ & 7 & It is not in accordance with \\
\hline 12 & Petualangan Mona & 8 & It is not in accordance with \\
\hline
\end{tabular}




\section{CONCLUSION}

This research has shown the importance of analyzing the readability of a textbook, especially on Indonesian language subjects. Raygor graphics are one of the measuring instruments that can be used to analyze the level of readability. The use of Raygor graphics allows the teacher to know quickly the level of readability of a textbook. Also at the same time selecting the most appropriate textbook for each grade level in terms of its level of readiness.

Another important finding in this study is the existence of a small dictionary placed at the bottom of each text which contains an explanation of some difficult words contained in the text. The existence of a small dictionary can help students understand the contents of the text.

\section{ACKNOWLEDGMENT}

We thank Asta Science Success Publishers (a member of the sun group) through Mr. Ifran Nurtriputra, M.Pd, for permission given to analyze the level of readability of one of the published textbooks. There were no grants received by Researchers in this study.

\section{REFERENCES}

[1] Republik Indonsia, "Undang-Undang Nomor 20 Pasal 1 Ayat (19) tentang Sistem Pendidikan Nasional." 2003.

[2] Kemendikbud, "Kurukulum 2013. Disampaikan pada Kongres XXI PGRI." 2013.

[3] Tim Penyusun, Model Silabus Sekolah Dasar/Madrasah Ibtidaiyah (SD/MI). Jakarta: Kementerian Pendidikan dan Kebudayaan, 2017.

[4] Republik Indonsia, "Peraturan Menteri Pendidikan Nasional No. 11 Pasal 1." 2005.

[5] A. Prastowo, Bahan Ajar Inovatif. Yogyakarta: Diva Press, 2013.

[6] Akbar, Instrumen Perangkat Pembelajaran, Kedua. Bandung: Remaja Rosda Karya Offset, 2013.

[7] F. R and M. M, "Buku Teks Bahasa Indonesia SMP dan SMA Kurikulum 2013 Terbitan Kementerian Pendidikan dan Kebudayaan 2014," J. Pena Indones. J. Bhs. Indones. Sastra, dan Pengajarannya, vol. 1, no. 1, pp. 26-49, 2015.

[8] A. Harjasujana and Y. Mulyati, Membaca 2. jakarta: Depdiknas, 1996.

[9] M. Zamanian and P. Heydari, "Readability of Texts: State of the Art," Theory Pract. Lang. Stud., vol. 2, no. 1, Jan. 2012.

[10] S. Arikunto, Prosedur Penelitian Suatu Pendekatan Praktik. Jakarta: Rineka Cipta, 2014.

[11] Setiawati, Datasets: Keterbacaan Buku Teks Bahasa Indonesia Kurikulum2013 Tingkat Sekolah Dasar Kelas V dengan Grafik Raygor. USA: Center for Open Science, 2018. 